\title{
Determining optimum configuration of one-way and two-way streets using shortest path travel costs based on results of traffic assignment
}

\section{En kısa rota seyahat süreleri kullanılarak tek ve iki yönlü yolların optimum düzenlemelerinin yapılması}

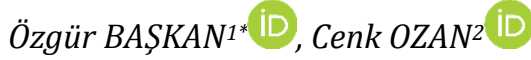

\begin{abstract}
1Department of Civil Engineering, Engineering Faculty, Pamukkale University, Denizli, Turkey.
\end{abstract} \\ obaskan@pau.edu.tr \\ ${ }^{2}$ Department of Civil Engineering, Engineering Faculty, Adnan Menderes University, Aydin, Turkey. \\ cenk.ozan@adu.edu.tr
}

Received/Geliş Tarihi: 21.07.2017, Accepted/Kabul Tarihi: 08.09.2017

doi: $10.5505 /$ pajes.2017.21208

* Corresponding author/Yazıșllan Yazar Research Article/Araștırma Makalesi

\begin{abstract}
Traffic congestion is one of the major problems in transportation field. To reduce unfavorable impact of that problem, one of the conventional applications is to find optimal or near-optimal configuration of one-way streets on road networks. When some of two-way streets in the network are converted to one-way, which may be cheaper than other possible improvements, the performance of the road system may increase. Thus, this arrangement should be evaluated in order to determine its possible effects. For this purpose, a bilevel heuristic solution algorithm is proposed to find optimal configuration of one-way streets on road networks in this study. The upper level deals with finding optimal configuration of one-way streets by minimizing the total flow (demand) weighted shortest path travel costs (distance) while user equilibrium link flows are determined in the lower level. Shortest path travel costs between $O D$ pairs are obtained after executing traffic assignment module of VISUM software by considering link travel times according to created network configuration in the upper level. To make more attractive one-way streets, we have used the parameter of $\alpha$ which is multiplied with the length of one-way streets to increase its speed. The bilevel heuristic solution algorithm is combined with VISUM and applied to Sioux-Falls city network. The results of near-optimal arrangement of one-way streets are compared with those of base case in terms of objective function considered. Additionally, sensitivity analysis was performed to investigate how the algorithm reacts to the variation of the parameter of $\alpha$. Results showed that developed algorithm may be considered for finding optimal configuration of one-way streets on urban road networks.
\end{abstract}

Keywords: Traffic management, One-way streets, Bilevel programming

\section{Introduction}

The use of motorized vehicles on urban roads has been growing day by day especially in last decades due to rapid increase in transport demand and low usage of public transportation systems as well. This fact leads to various traffic problems although some countermeasures are taken by local authorities to minimize their negative effects. One of these problems generally occurred at intersections of urban road networks is traffic congestion phenomenon. To reduce the negative impacts of that problem, optimization of signal timing plans, reconfiguration of intersection geometry and increasing of link capacities can be used as efficient solutions. Besides, one of these applications is to find optimum arrangement of one-way

\section{Öz}

Ulaștırma alanındaki en önemli problemlerden biri bilindiği gibi trafik sıkışıklığıdır. Trafik sıkışıklı̆ıının olumsuz etkilerini en aza indirebilmek için uygulanan geleneksel yöntemlerden biride tek yön uygulamalarıdır. Kentiçi yol ağlarındaki iki yönlü yolların bazılarının tek yöne çevrilmesi uygulaması bilindiği gibi sistem performansını artırmaya yönelik diğer uygulamalardan daha az maliyetlidir. Bu nedenle tek yön uygulamalarının ağ performansı üzerindeki olası etkilerinin değerlendirilmesi gerekmektedir. Calıșmada bu amaçla yol ağlarındaki tek yönlü yolların optimum konfigürasyonun belirlenmesi amacıyla iki seviyeli sezgisel bir çözüm algoritması geliștirilmiștir. Üst seviyede talep ağırlıklı en kısa rota seyahat sürelerinin toplamının en küçüklenmesi amaçlanmıștır. Alt seviyede ise kullanıcı dengesi bağ akımları belirlenmistir. Üst seviyede olusturulan ağ yapısına bağlı olarak belirlenen bağ seyahat süreleri dikkate alınarak trafik atama problemi VISUM yazılımı ile çözülmüș ve Bașlangıç-Varıș (B-V) çiftleri arasındaki en kısa rota seyahat süreleri elde edilmiștir. Tek yönlü yolların daha cazip hale getirmek amaciyla a parametresi kullanılmıștır. Bu amaçla ulașım ağı içinde tek yöne çevrilen bağların uzunluğu a parametresi ile çarpılarak azaltılmış bir başka deyişle bağ üzerindeki hız artırılmıstır. Gelistirilen iki seviyeli sezgisel çözüm algoritması Sioux-Falls ulaşım ağına uygulanmıștır. Bazı bağların tek yön olması durumundaki sonuçlar ağdaki tüm bağların çift yönlü hizmet vermesi durumuna göre geliștirilen amaç fonksiyonu değerlendirilerek karşılaştırılmıștır. Ayrıca $\alpha$ parametresine karşı geliștirilen algoritmanın duyarlılığını test etmek amacıyla duyarlılık analizi yapılmıştır. Sonuçlar gelişstirilen algoritmanın kentiçi ulaşım ağlarında yapılması planlanan tek yön uygulamalarında kullanılabileceğini göstermektedir.

Anahtar kelimeler: Trafik yönetimi, Tek yön, İki seviyeli programlama

streets in which traffic moves in a single direction. With this application, total travel times in the road network may be decreased by reducing travel times of one-way streets.

Although the studies related to optimum arrangement of oneway streets on urban road networks are quite limited, especially in last two decades, some researchers have studied on this issue and investigated this problem in many aspects. Lee and Yang [1] used simulated annealing algorithm, which is a metaheuristic to reach to global solution in a large search space, for finding optimal configuration of one-way streets on urban road networks. Results showed that the proposed algorithm was found useful to solve discrete equilibrium network design problem for planning one-way streets on urban roads. Drezner and Wesolowsky [2] aimed to reduce the total flow-weighted 
travel time by arranging of one-way streets. For this purpose, an exact algorithm, several heuristic methods and simulated annealing algorithm are compared with each other and results are discussed. Drezner and Salhi [3] focused on finding one-way streets using tabu search algorithm. This approach was tested on several test networks. For optimal configuration of one-way streets on road networks, hybrid metaheuristic algorithms are also used and encouraging results were obtained. Drezner and Salhi [4] proposed simulated annealing and genetic algorithms for finding optimal solution of this problem on large-sized networks. Then, tabu search algorithm has been applied on the solutions of these metaheuristics. It was concluded that genetic algorithm performed better than simulated annealing. Ozan and Baskan [5] developed a bilevel heuristic solution algorithm based on harmony search algorithm to find optimum arrangement of one-way and two-way streets on urban road networks. Results emphasized that developed algorithm may be taken into account for the solution of this problem.

From a different viewpoint, Drezner and Wesolowsky [6] combined two objectives in the context of road network design. They assumed that each street in the network may be built or not. Also, each street may serve to vehicles as one-way or twoway. Under these assumptions, four main problems are presented and these problems are solved by using different methods available in the literature. Zargari and Taromi [7] used genetic algorithm for finding optimum arrangement of one-way streets in a real city network. In their study, minimization of total travel cost was aimed. Results obtained by using genetic algorithm were compared with current situation. Miandoabchi and Farahani [8] proposed a solution algorithm for discrete road network design problem which consists of arrangement of one-way streets in the network. Numerical examples are conducted on a number of test networks. Results indicated that the developed multi-objective algorithm performs better than the other compared algorithms. Salcedo-Sanz et al. [9] investigated the rearrangement of two-way streets on urban roads to reduce total travel cost of all users. For this purpose, a new definition is formulated, and a novel multi-objective harmony search algorithm is developed. The efficiency of the proposed definition and its solution algorithm are tested in several test networks. Similarly, simulated annealing algorithm for finding optimal arrangement of one-way streets was used in Poorzahedy and Shirazi [10]. Results of simulated annealing approach are compared with another heuristic approach. Some suggestions and future directions on this problem are given. Salcedo-Sanz et al. [11] studied on planning of urban roads which consists of rearrangement of direction of the streets. In their study, the problem is defined as a multi-objective optimization case and solved by using an evolutionary algorithm and its performance is tested in a real city. On the other hand, the configuration of one-way and two-way links on transportation road networks plays an important role at the emergency evacuation conditions as well. In this context, Afandizadeh et al. [12] studied on finding of optimal network configuration in case of emergency evacuation by using simulated annealing algorithm. Similarly, Afandizadeh et al. [13] evaluated emergency evacuation conditions by minimizing total travel time of all users. Optimal arrangement of one-way and two-way links was determined using simulated annealing algorithm and results showed that proposed model is able to provide lower total travel time than base case.

Although the solution methods developed so far are able to find the optimal arrangement of one-way streets, an investigation of performances of different objective functions is needed. Therefore, we propose a bilevel heuristic solution algorithm based on Differential Evolution algorithm to find optimal arrangement of one-way and two-way streets on urban road networks. The upper level deals with making optimal arrangement of one-way streets by minimizing the total flow (demand) weighted shortest path travel costs (distance) while user equilibrium link flows are found by solving traffic assignment problem in the lower level according to created network configuration in the upper level. In order to test the proposed algorithm, Sioux-Falls city network was considered. The rest of this paper is organized as follows. Problem formulation is explained in the next section. In Section 3, bilevel heuristic solution algorithm is presented. Numerical application is conducted in Section 4. Conclusions and possible future studies are given in the last section.

\section{Problem formulation}

As known, Discrete Network Design Problem (DNDP) includes building new roads, increasing or decreasing of the number of lanes, and determining the directions of one-way streets and it only deals with discrete design decisions [14]. Therefore, optimal arrangement of one-way streets in a given road network can be solved in the context of DNDP. Since it is considered as NP-hard, the exact methods such as the Branch and Bound method cannot solve this problem efficiently. Therefore, a large amount of solution methods in this field consists of meta-heuristics. On the other hand, this problem may be considered as leader-follower, where the local authority is the leader and the users are the followers [15]. In this context, it is supposed that the local authority may affect the users' route choice behavior by reconfiguration of one-way streets. Conversely, the users make their route choice decision by minimizing own travel costs under given structure of a road network [16]. Thus, this interaction may be taken into consideration as bilevel modelling. It seems obvious that it contains two levels, which are upper and lower levels [17].

The upper level deals with finding optimal arrangement of oneway streets on a road network by minimizing total flow (demand) weighted shortest path travel costs (distance) while User Equilibrium (UE) link flows are found in the lower level by considering network configuration in the upper level. The objective function of the upper level is formulated as

$$
\min \sum_{(r, s) \in D} d_{r s} s_{r s}(\mathbf{z})
$$

subject to

$$
\begin{gathered}
\mathbf{z}=\left(z_{1}, z_{2}, z_{3}, \ldots, z_{a}, \ldots\right) \quad \forall a=1,2, \ldots, A \\
z_{a}=0 \text { or } 1 ; \quad \forall a=1,2, \ldots, A \\
n_{\text {in }} \geq 1 \quad \forall n \\
n_{\text {out }} \geq 1 \quad \forall n \\
K_{\text {rs }} \geq 1 \quad \forall r, s
\end{gathered}
$$

Where $d_{r s}$ is the travel demand from origin $r$ to destination $s$, $s_{r s}(\mathbf{z})$ is the distance of shortest path from $r$ to $s$ defined by $\mathbf{z}$. Besides, we have used the factor of $\alpha$ in order to reduce travel times of one-way streets. To do this, the length of link $a$ is multiplied by $\alpha$ when opposite link is closed since the speed on one-way links is greater than the two-way links. In other words, 
the speed is increased by the factor of $(1 / \alpha)$ when a link is used as one-way. The objective function given in Eq. (1) deals with minimization of total flow (demand) weighted shortest path travel costs (distance) in the network. The possible state of each link (i.e. in use or not) in the network is presented discrete decision variables $(0,1)$ by each member of vector of $\mathbf{z}$ as given in Eqs. (2-3). When a link is closed from node $n$ to node $n+1$, it means that the opposite link is turned into one-way link which is from node $(n+1)$ to node $n$. On the other hand, each node in the network should have at least one incoming and outgoing links. These constraints are given in Eq. (4) and (5). Besides, each origin and destination must be connected at least with one path which is provided in Eq. (6).

User Equilibrium (UE) traffic assignment has been performed in the lower level considering network configuration created in the upper level to find shortest path travel costs (distance) according to the equilibrium link flows. In UE assignment, demands are distributed according to Wardrop's first principle which states that the travel times of all used paths between the same 0-D pair are equal and less than any unused paths [18]. It should be noted that this assumption is the most widely used approach in order to find the equilibrium link flows in road network design problems. In this study, the user's route choice behavior is defined by performing UE assignment which can be formulated as follows:

$$
\min \sum_{a \in A} \int_{0}^{x_{a}} t_{a}(w) d w
$$

subject to

$$
\begin{array}{cc}
\sum_{k \in K} f_{k}^{r s}=D_{r s} & \forall r \in R, s \in S, k \in K_{r s} \\
x_{a}=\sum_{r s} \sum_{k \in K_{r s}} f_{k}^{r s} \delta_{a, k}^{r s} & \forall r \in R, s \in S, a \in A, k \in K_{r s} \\
f_{k}^{r s} \geq 0, & \forall r \in R, s \in S, k \in K_{r s}
\end{array}
$$

Total traffic volume of all routes has to be equal to the demand from origin $r$ to destination $s$ as shown in Eq. (8). Eq. (9) shows volume on link $a$ resulted from the sum of volumes of all routes which contain this link. The volume of all routes must be positive as given in Eq. (10).

Since UE assignment is a convex problem, it can be numerically solved by various methods. In this study, VISUM [19] is used for finding equilibrium link flows at the lower level. VISUM provides various UE assignment models such as Incremental assignment, Equilibrium assignment, etc. As different models serve different objectives, Equilibrium assignment module has been used by considering the objective of this study. This assignment module provides more realistic results since its procedure is only terminated when all routes of any OD pair are in the balanced state. Another reason for the use of VISUM is that it can be embedded into the proposed solution algorithm using VBA programming language. Thus, analysis and some modifications can be easily performed.

\section{Bilevel heuristic solution algorithm}

In this study, a bilevel heuristic algorithm is developed to find optimum arrangement of one-way streets on urban road networks. An optimization procedure based on Differential Evolution (DE) is embedded into the algorithm to solve minimization problem given in Eq. (1). The optimum arrangement of one-way streets is found in the upper level while the shortest path travel costs (distance) are found in the lower level by using VISUM. The proposed algorithm is coded in VBA programming language due to outstanding advantages of VISUM that allows to import and export data using VBA. Because of being quite robust and reliable for solving of complex optimization problems, decision variables are generated by using DE algorithm in the upper level. The DE is a quite simple and efficient meta-heuristic algorithm in which the initial population is improved to find the global or near-global optimum through repeated cycle of mutation, crossover and selection procedures [20]-[25]. In the DE, two fundamental control parameters are utilized to conduct the optimization process. The first one is the Mutation Factor $(F)$ which is used to obtain mutant vector from selected three solution vectors in the population and the second one is the Crossover Rate $(C R)$

\begin{tabular}{|c|c|c|c|c|c|c|c|c|c|c|}
\hline$z_{1}^{1}$ & $z_{2}^{1}$ & $z_{3}^{1}$ & $z_{4}^{1}$ & $z_{5}^{1}$ & $\ldots$ & $\ldots$ & $z_{a}^{1}$ & $\ldots$ & $\ldots$ & $z_{A}^{1}$ \\
\hline$z_{1}^{2}$ & $z_{2}^{2}$ & $z_{3}^{2}$ & $z_{4}^{2}$ & $z_{5}^{2}$ & $\ldots$ & $\ldots$ & $z_{a}^{2}$ & $\ldots$ & $\ldots$ & $\overline{z_{A}^{2}}$ \\
\hline$z_{1}^{3}$ & $z_{2}^{3}$ & $z_{3}^{3}$ & $z_{4}^{3}$ & $z_{5}^{3}$ & $\ldots$ & $\ldots$ & $z_{a}^{3}$ & ... & $\ldots$ & $z_{A}^{3}$ \\
\hline$\checkmark$ & $\checkmark$ & 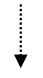 & 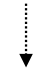 & $\dot{\nabla}$ & 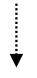 & $\dot{\nabla}$ & 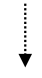 & $\dot{\nabla}$ & 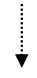 & 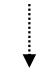 \\
\hline$z_{1}^{p}$ & $z_{2}^{p}$ & $z_{3}^{p}$ & $z_{4}^{p}$ & $z_{5}^{p}$ & $\ldots$ & $\ldots$ & $z_{a}^{p}$ & $\ldots$ & $\ldots$ & $z_{A}^{P}$ \\
\hline
\end{tabular}
that is the probability of consideration of the mutant vector (see for details Storn and Price [26]). The upper level decision variables are generated as in Figure(1).

Figure 1: Representation of upper level decision variables.

In Figure(1), $a$ represents the number of decision variables (i.e. the number of links) and $p$ is the number of population in the DE. Similarly to other meta-heuristic algorithms, each row of population is randomly filled by variables of 0 or 1 (if this value is 0 , the link is closed) and so called target vector is created. After creating all target vectors, the decision variables are input to VISUM and shortest path travel costs (distance) are determined by executing traffic assignment module in VISUM. Thus, the objective function values can be calculated for target vectors by using Eq. (1). After then, each element of a mutant vector is obtained from randomly selected three solution vectors using Eq. (11).

$\lambda_{j}^{i, u}=z_{j}^{1, u}+F\left(z_{j}^{2, u}-z_{j}^{3, u}\right) \quad i=1,2, \ldots, p ; j=1,2, \ldots, A$

Where $z_{j}^{1, u}, z_{j}^{2, u}$ and $z_{j}^{3, u}$ are randomly taken decision variables within the range $[1, p]$ at generation $u, A$ is the total number of upper level decision variables and $z_{j}^{1, u} \neq z_{j}^{2, u} \neq z_{j}^{3, u}$. After creating the mutant vector for each target vector, the other improvement process of the DE is performed using crossover operator to obtain trial vector. At this stage, each value of trial vector, $\omega_{j}^{i, u}$, is selected from the mutant vector or from the target vector depending on the value generated between 0 and 1 as shown in Eq. (12).

$$
\omega_{j}^{i, u}=\left\{\begin{array}{l}
\lambda_{j}^{i, u}, \text { if rand }(0,1) \leq C R \text { or } i=i_{\text {rand }} \\
z_{j}^{i, u}, \text { otherwise }
\end{array}\right\}
$$

As can be seen on Eq. (12), the value of the $(C R)$ is compared with random number between 0 and 1 . The aim of this comparison is to determine whether the member of the trial vector is taken from mutant vector or target vector. If the value 
generated between 0 and 1 is less than $(C R)$ or equal to $(C R)$ at generation $u$, the member of trial vector is chosen from the mutant vector; otherwise it is chosen from the target vector. The constraint of $i=i_{\text {rand }}$ provides that at least one member of the trial vector is taken from the mutant vector to diversify the population. Then the trial vector $\boldsymbol{\omega}^{u}$ is compared with the target vector considering their fitness values. At this step, decision variables ( 0 or 1 ) are input to VISUM for determining fitness value of trial vector and traffic assignment process is executed. After then, the fitness value of trial vector is calculated using Eq. (1). Finally, the objective function values of trial and target vectors are compared to each other. The best one is taken to the generation $(u+1)$ and the other is ignored. Iterative solution process is repeated until maximum number of generations is reached. The algorithm steps are given in Figure (2).
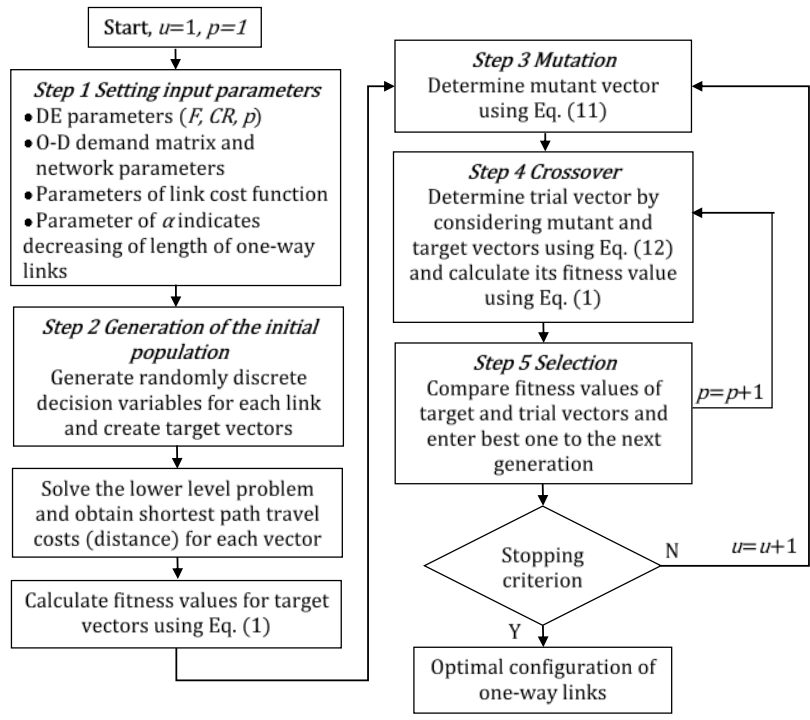

Figure 2: Flowchart of the proposed algorithm.

\section{Numerical application}

In this section, the Sioux Falls city network is used in order to test the proposed algorithm. The link parameters and peakhour travel demands are taken from Baskan [16]. It is assumed that each link has two lanes in the network. The travel cost function is used as given in Eq. (13).

$$
t_{a}\left(x_{a}\right)=\tau_{a}+\sigma_{a}\left(x_{a} / \theta_{a}\right)^{4}
$$

Where $\tau_{a}, \sigma_{a}$ are the parameters and $\theta_{a}$ is the capacity for link $a, \forall a \in A$. The parameters of the $\mathrm{DE}(F, C R$ and $p)$ are selected $0.8,0.8$ and 10 , respectively in keeping with the literature. The value of $\alpha$, by which link lengths are multiplied when the opposite links are closed, is taken as 0.5 to reflect the increase of speed on a one-way link. At the lower level, UE is conducted by way of VISUM. It is supposed that the algorithm has reached to optimum or near-optimum solution when the maximum number of generations is reached which is taken as 30 . The convergence graph of the proposed algorithm can be seen in Figure (3).

In case of all links in the network are operated as two-way, the objective function value is found as 4824 . In the initialization process, the proposed algorithm randomly generates upper level decision variables and thus the initial population is created. The best value of objective function in the initial population is found as about 4730. After then mutation, crossover and selection operators are applied to initial population and the final objective function value is obtained as about 4386 when links 6, 21 and 23 are closed as shown in the network given in Figure (4). This means that links 8, 24 and 13 are operated as one-way links. When the final objective function value is compared with the value of base case which represents that no link is closed, total flow-weighted shortest path travel costs (distance) is reduced about $10 \%$ in the overall network by reconfiguration of the network. At this point, it should be emphasized that the value of $\alpha$ is key parameter since the different $\alpha$ values may lead to various improvement rates.

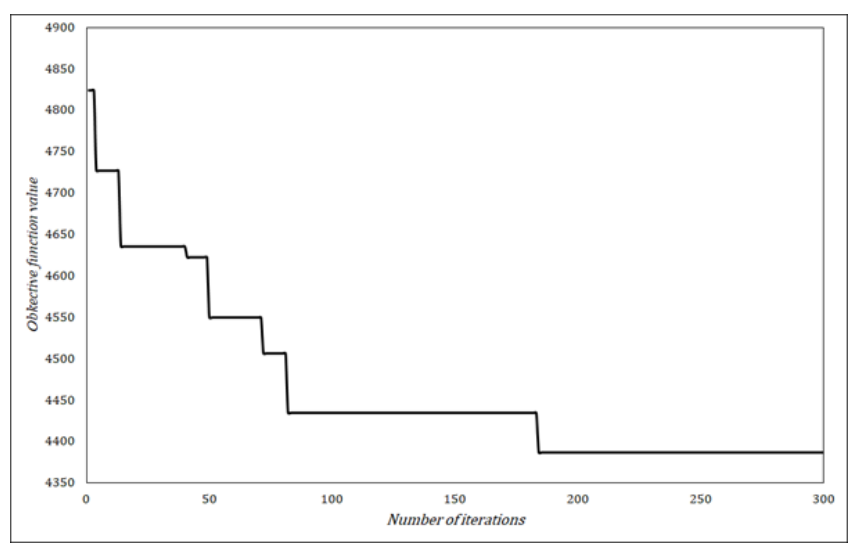

Figure 3: Convergence graph of the proposed algorithm.

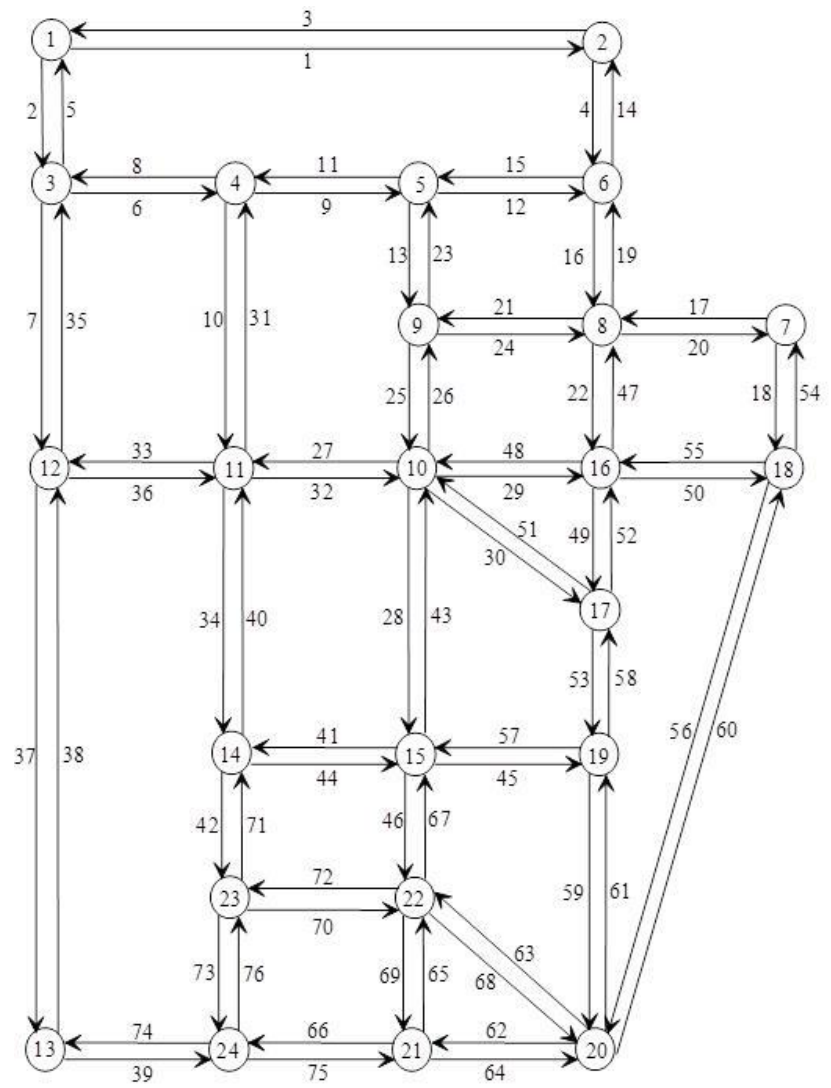

Figure 4: Sioux-Falls city network. 


\subsection{Sensitivity analysis of parameter $\alpha$}

An additional analysis has been conducted to investigate how the proposed algorithm is affected when the parameter of $\alpha$ is changed. The sensitivity analysis is performed by comparing the convergence graphs of the algorithm with respect to the different $\alpha$ values which vary from 0.5 to 1 . As aforementioned, the value of $\alpha$ is multiplied with the length of link to reflect the increase of speed on one-way links, and to make it more attractive by the users on the road network. As expected, the high values of $\alpha$ cause early convergence of the proposed algorithm as can be seen in Figure (5). Road users do not notice the advantages of one-way links in terms of the increase of their speed since the decrease of the length of one-way links is not significant with use of high values of $\alpha$. On the other hand, the low values of $\alpha$ provide that one-way links may be more attractive due to increase of their speed, and this may lead to increasing its choice probability by the users.

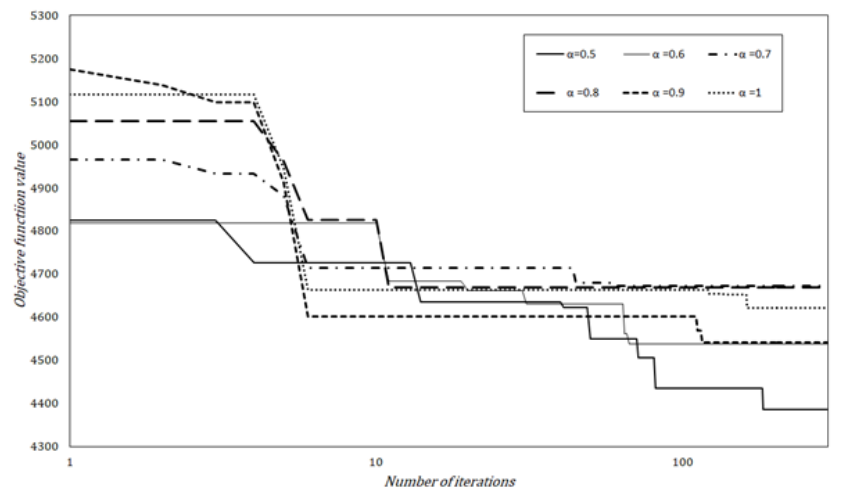

Figure 5: Comparing of the convergence graphs for different $\alpha$ values.

\section{Conclusion}

This study aims to find optimal design of a road network which may include one-way and two-way streets. For this purpose, a heuristic solution algorithm is developed using bilevel modelling approach. The upper level aims to minimize total flow-weighted shortest path travel costs (distance) while the UE link flows are found by VISUM at the lower level. In order to test the proposed algorithm, Sioux Falls city network is used which is probably most preferable test network in the literature. Results revealed that the proposed algorithm is able to reduce total flow-weighted shortest path travel costs (distance) about $10 \%$ by optimal arrangement of one-way streets in the network in comparison to the base case. Additionally, sensitivity analysis has been performed in order to see how the developed algorithm is affected by changing the parameter of $\alpha$. In future, the proposed algorithm will be applied to a signalized road network in order to investigate possible effects of signal timings and phase plans in the solution of that problem.

\section{References}

[1] Lee CK, Yang KI. "Network design of one-way streets with simulated annealing". Papers in Regional Science, 73(2), 119-134, 1994.
[2] Drezner Z, Weselowsky GO. "Selecting an optimum configuration of one-way and two-way routes". Transportation Science, 31, 386-394, 1997.

[3] Drezner Z, Salhi S. "Selecting an optimum configuration of one-way and two-way routes using tabu search". Kyoto University Research Information Repository, 1068, 203-215, 1998.

[4] Drezner Z, Salhi S. "Using hybrid metaheuristics for the one-way and two-way network design problem". Naval Research Logistics, 49(5), 449-463, 2002.

[5] Ozan C, Baskan 0. "Implementation of one-way streets using shortest path distances on urban road networks". $12^{\text {th }}$ Transportation Congress, Adana, Turkey, 24-26 May 2017. (in Turkish).

[6] Drezner Z, Weselowsky GO. "Network design: Selection and design of links and facility location". Transportation Research Part- A, 37, 241-256, 2003.

[7] Zargari SA, Taromi R. "Selecting an optimum configuration of urban one-way and two-way streets using genetic algorithms". International Journal of Civil Engineering, 4(3), 244-259, 2006.

[8] Miandoabchi E, Farahani RZ. "Bi-objective bimodal urban road network design using hybrid metaheuristics". Central European Journal of Operations Research, 20, 583-621, 2012.

[9] Salcedo-Sanz S, Manjarres D, Pastor-Sanchez A, Del Ser J, Portilla-Figureas JA, Gil-Lopez S. "One-way urban traffic reconfiguration using a multi-objective harmony search approach". Expert System with Applications, 40(9), 3341-3350, 2013.

[10] Poorzahedy H, Shirazi DM. "A simulated annealing approach to solve the network design of one-way streets: case of shiraz network". Computational Methods in Civil Engineering, 4(1), 83-101, 2013.

[11] Salcedo-Sanz S, Cuadra L, Alexandre-Cortizo E, JimenezFernandez S, Portilla-Figueras A. "Soft-Computing: An innovative technological solution for urban traffic-related problems in modern cities". Technological Forecasting \& Social Change, 89, 236-244, 2014.

[12] Afandizadeh S, Jahangiri A, Kalantari N. "Determination of the optimal network configuration for emergency evacuation by simulated annealing algorithm". Proceeding of the 2nd WSEAS International Conference on Natural Hazards, Baltimore, USA, 65-71, 2009.

[13] Afandizadeh S, Jahangiri A, Kalantari N. "Identifying the optimal configuration of one-way and two-way streets for contraflow operation during an emergency evacuation". Natural Hazards, 69, 1315-1334, 2013.

[14] Farahani RZ, Miandoabchi E, Szeto WY, Rashidi, H. "A review of urban transportation network design problems". European Journal of Operational Research, 229(2), 281-302, 2013.

[15] Fisk C. "Optimal signal controls on congested networks". $9^{\text {th }}$ International Symposium on Transportation and Traffic Theory, Delft, Netherlands, 11-13 July, 1984.

[16] Baskan 0. "Determining optimal link capacity expansions in road networks using cuckoo search algorithm with levy flights". Journal of Applied Mathematics, 2013, 1-11, 2013.

[17] Baskan 0. "Harmony search algorithm for continuous network design problem with link capacity expansions". KSCE Journal of Civil Engineering, 18(1), 273-283, 2014.

[18] Wardrop JG. "Some theoretical aspects of road traffic research". Proceedings of the Institution of Civil Engineers Part II, 1, 325-378, 1952. 
[19] PTV Planung Transport Verkehr AG. "VISUM 14-User Manual". Karlsruhe, Germany, 2014.

[20] Liu H, Cai Z, Wang Y. "Hybridizing particle swarm optimization with differential evolution for constrained numerical and engineering optimization". Applied Soft Computing, 10(2), 629-640, 2010.

[21] Baskan 0. "Solving combined road network design problem using differential evolution algorithm". 10 th Transportation Congress, Izmir, Turkey, 24-26 September 2013. (in Turkish).

[22] Baskan O, Ceylan H. "Modified differential evolution algorithm for the continuous network design problem". $16^{\text {th }}$ Meeting of Euro Working Group on Transportation, Porto, Portugal, 4-6 September 2013.

[23] Baskan 0. "An evaluation of heuristic methods for determining optimal link capacity expansions on road networks". International Journal of Transportation, 2(1), 77-94, 2014.

[24] Baskan 0, Ceylan H. "Differential evolution based solution approaches for solving transportation network design problems". Pamukkale University Journal of Engineering Sciences, 20(9), 324-331, 2014.

[25] Baskan 0, Ozan C. "Combined solution of capacity expansion and signal setting problems for signalized road networks". 18 th Meeting of Euro Working Group on Transportation, TU Delft, The Netherlands, 14-16 July 2015.

[26] Storn R, Price K. "Differential Evolution: A Simple and Efficient Adaptive Scheme for Global Optimization over Continuous Spaces". International Computer Science Institute, Berkeley, USA, Technical Report, TR-95-012, 1995.

\section{Appendix A}

\subsection{Nomenclature}

A : The set of streets in the network,

$K_{r s} \quad$ : The set of paths between O-D pair $r s, \forall r \in R, s \in$ $S$,

$a \quad$ : Represents $a$ link in the network, $\forall a \in A$,

$n$ : Represents a node in the network,

$n_{\text {in }}$ : The number of incoming links for node $n$,

$n_{\text {out }}$ : The number of outgoing links for node $n$,

$R \quad: \quad$ The set of origins,

$S \quad$ : The set of destinations,

D : The vector of O-D pair demands, $\mathbf{D}=\left[D_{r s}\right], \forall r \in$ $R, s \in S$,

f : The vector of path flows, $\mathbf{f}=\left[f_{k}^{r s}\right], \forall r \in R, s \in$ $S, k \in K_{r s}$,

t : The vector of link travel times, $\mathbf{t}=\left[t_{a}\left(x_{a}\right)\right], \forall a \in$ $A$,

$\mathbf{x} \quad: \quad$ The vector of link flows, $\mathbf{x}=\left[x_{a}\right], \forall a \in A$,

$d_{a} \quad$ : The set of feasible decisions for link $a$ that is a subset of $\{0,1\}$,

$z_{a} \quad$ : Represents whether link $a$ is closed or not, it equals 0 if link $a$ is closed,

$\mathbf{z} \quad:\left(z_{1}, z_{2}, \ldots, z_{a}, \ldots\right)$ represents of one-way and two-way links,

$\delta_{a, k}^{r s} \quad: \quad$ the link/path incidence matrix variables $\forall r \in R$, $s \in S, k \in K_{r s}, \forall a \in A$,

$\alpha \quad: \quad$ The factor by which link lengths are multiplied when the opposite links are closed $(\alpha<1)$,

$F \quad$ : Mutation factor,

CR : Crossover rate,

$u$ : Number of generation,

$\lambda^{u} \quad$ : Mutant vector at generation $u$

$\boldsymbol{\omega}^{u} \quad$ : Trial vector at generation $u$

$p \quad$ : Number of population. 